\title{
Grêmio Esportivo Rui Barbosa: um espaço comunitário dos residentes do bairro Porto (Pelotas-RS, 1986-2004)
}

\author{
Letícia Portella Milan* \\ ORCID iD 0000-0002-6899-0472 \\ Universidade Federal de Santa Catarina, Pós Graduação em História, Florianópolis, Brasil
}

Resumo: O presente artigo é resultado de uma pesquisa que desvela memórias sobre vivências de frequentadores do Grêmio Esportivo Rui Barbosa, um clube de futebol amador localizado no bairro Porto, na cidade de Pelotas (RS). O bairro Porto é historicamente conhecido como um espaço industrial da cidade, no qual existiam inúmeras associações esportivas de futebol amador composta por operários. Neste texto, objetiva-se analisar o período temporal em que o clube foi apenas um espaço comunitário de sociabilidades, dando enfoque ao significado das vivências cotidianas dos moradores do bairro nesse espaço. A partir do escopo documental constituído de seis entrevistas com frequentadores do clube, fotografias e um livro de atas pretende-se situar o clube como um "lugar de memória", onde as festividades e as redes de amizades são memórias que constituem partes de muitas histórias: do bairro, da vida dos moradores, e do Grêmio Esportivo Rui Barbosa.

Palavras-chave: Futebol. Bairro. Pelotas.

\section{Grêmio Esportivo Rui Barbosa: a community space of residents of Porto district (Pelotas-RS, 1986-2004)}

Abstract: This paper is the result of a research that sought to unveil memories of experiences of individuals who attended Grêmio Esportivo Rui Barbosa, an amateur football club located at the Porto district in Pelotas (RS). Historically, Porto district was known as an industrial area of the city, where a number of amateur football sports associations composed by blue-collar workers existed. The goal of this paper

Doutoranda em História pela Universidade Federal de Santa Catarina (UFSC); Mestre em História pela Universidade Federal de Pelotas (UFPel); Bacharel e Licenciada em História pela Universidade Federal de Santa Maria (UFSM). E-mail: leticiapmilan@gmail.com. 
is to analyze the period in which the club was solely a communal space for sociability, focusing on the meaning of the everyday experiences that the Porto inhabitants had in this space. With a documental scope consisting of six interviews with clubgoers, photographs, and a book of minutes, this paper seeks to situate the club as a "site of memory", where festivities and friendship networks are regarded as memories that constitute different pieces of many stories: of the district, of the life of its inhabitants, and of the Grêmio Esportivo Rui Barbosa.

Keywords: Football. District. Pelotas.

\section{A construção da pesquisa: entrelaçamentos entre a história de vida da pesquisadora e o objeto de pesquisa}

Quantas pesquisas surgem quando nos deparamos com algo que não esperávamos encontrar? A história da formação do Grêmio Esportivo Rui Barbosa ${ }^{1}$ foi uma descoberta inesperada, embora sua existência fosse uma presença na minha vida desde a infância. A escolha desse objeto de pesquisa e os questionamentos sobre ele surgiram em um momento de formação profissional, quando eu era estudante do curso de graduação em História, na Universidade Federal de Santa Maria (UFSM). Para a construção do projeto de pesquisa, além dos elementos intrínsecos como tema, metodologia e objetivos, também era necessário apresentar a maneira como cheguei ao objeto de pesquisa. Contudo, narrar essa trajetória externaria algo que na época parecia ser uma ameaça para minha "seriedade" enquanto pesquisadora: revelar que existia um entrelaçamento entre o objeto e a minha trajetória de vida. Naquele momento, explicitar esse aspecto parecia ser "pouco científico", já que no meu imaginário uma boa análise histórica só era possível a partir de uma impessoalidade em relação ao objeto de pesquisa. De forma positiva, o amadurecimento e a experiência com novos campos da historiografia transformaram essa perspectiva enrijecida em um aprendizado inestimável sobre a importância da subjetividade e da experiência humana na História. Nessa direção, as leituras sobre História Oral conduziram minha formação e, por meio delas, meu entendimento de que nem a impessoalidade ou a subjetividade diminuem o valor científico de uma pesquisa em detrimento de outras, construídas a partir de "documentos oficiais".

Desse modo, o reconhecimento da existência de diversos tipos de fontes históricas

1 No decorrer do artigo, o leitor perceberá que o nome original do clube é Grêmio Sportivo Ruy Barbosa, sendo abreviado pelos jornais da cidade e referências bibliográficas como G. S. Ruy Barbosa. O nome atual do clube é Grêmio Esportivo Rui Barbosa. Não se sabe quando ocorreu essa mudança, contudo, foi possível notar que em meados dos anos de 1940 o clube já era chamado assim. No presente artigo, optei por chamá-lo pelo nome atual, Grêmio Esportivo Rui Barbosa", e para facilitar a leitura abreviarei para G. E. Rui Barbosa. 
me inspirou a ter confiança em formular uma pesquisa e uma forma de escrita que pretendesse inserir, na historiografia, lugares e pessoas que estâo fora dos documentos oficiais escritos. Em suma, pesquisar um clube que no passado esteve presente em minha vida e ter me aprofundado tanto na teoria quanto na metodologia da História Oral significou, para minha formaçáo profissional, o desenvolvimento da percepção de que atores sociais e objetos materiais, que a princípio jamais seriam vistos e reconhecidos pela sociedade, necessitam da atençáo de pesquisadores que ouçam e reconstruam suas histórias.

Por isso, para a compreensão do caminho da pesquisa, é preciso entender um pouco a dinâmica da minha história com o objeto, ou seja, o clube Grêmio Esportivo Rui Barbosa. Nascida no Rio Grande do Sul, na cidade de Pelotas, passei a maior parte da vida morando longe de minha família. A distância fazia com que, em datas especiais, eu viajasse para visitá-los. Frequentar a casa de minha avó significava vivenciar a rotina de várias pessoas e os hábitos da vizinhança no comércio local, das quitandas, lojinhas e padarias. Experimentar esse cotidiano me levou a observar essas formas de interaçáo com mais atençấo e interesse. No ano de 2014, em mais uma viagem costumeira para as festividades do final de ano, cheguei à casa de minha avó e, como costume dos moradores do bairro, sentei-me em uma cadeira na calçada em companhia de meus tios e vizinhos. No final da tarde, quando a conversa já havia cessado, avistei ao final da rua uma casa que me era bastante familiar. Durante minha infância, o local era chamado de "Rui" e funcionava como um saláo de festas para os aniversários dos residentes do bairro, principalmente das crianças (assim como eu, que tive alguns aniversários comemorados lá). Visualmente, a casa se mantinha idêntica à minha memória, porém a sensação ao avistá-la era diferente, pois naquele instante senti o ímpeto de compreendêla com mais profundidade. Para aqueles que estavam sentados em minha companhia, fiz a seguinte pergunta: "De quem é o Rui? Ainda funciona como saláo de festas?". A partir desse simples questionamento, surgiu uma resposta complexa: "Antes de ser um saláo de festas, o Rui Barbosa era a sede de um clube de futebol amador chamado Grêmio Sportivo Ruy Barbosa”. Naquele momento, a revelaçáo do nome oficial do saláo despertou um senso investigativo que resultou em um projeto de pesquisa desenvolvido e finalizado em 2014.

Com o intuito de construir uma pesquisa focada na oralidade dos frequentadores do clube, autores como Verena Alberti, José Carlos Sebe Bom Meihy, Valdete Boni e Sílvia Jurema Quaresma foram basilares nos aportes teóricos metodológicos da História Oral, na construçáo de um roteiro de perguntas estruturado de acordo com os objetivos da pesquisa e nas técnicas de condução das entrevistas. Desse modo, Alberti (2004) explicita de forma singular os campos e temas que uma entrevista de História Oral desvela. A partir disso, identifiquei que a pesquisa sobre o G. E. Rui Barbosa contribuía para a história da comunidade do bairro Porto e a história das experiências desses moradores na construçáo de um ambiente comunitário, como o referido clube. Dito isto, identificar esses dois campos facilitou a construção de um roteiro de entrevistas. 
Logo, a definição de História Oral temática posta por Meihy (2005) serviu como guia para perguntas que contribuíssem de forma efetiva na coleta de informaçóes sobre os seguintes pontos: o passado da formaçáo do clube, sua importância para a vida dos residentes do bairro Porto, a forma como essas pessoas conheceram o clube e quais lembranças têm sobre suas vivências nesse espaço. As técnicas de entrevistas para Ciências Sociais desenvolvidas por Boni e Quaresma (2005) foram valiosas para este trabalho. Entre os variados tipos de entrevistas explicitados pelas autoras, optei por formular entrevistas semiestruturadas, pois essas permitem uma articulaçáo de perguntas abertas e fechadas sobre o tema.

Para seu desenvolvimento, entrei em contato com todos os moradores da rua; alguns demonstraram interesse em marcar uma conversa para falar sobre o clube e outros indicaram pessoas que já não residiam no bairro, mas que moravam próximo dali. Desse modo, meu critério de escolha para possíveis participantes foi pessoas que estiveram em contato com as atividades do clube, independentemente do contexto de participação, ou seja, tanto na prática esportiva como na participação das festividades desenvolvidas no local da sede. Em razão da ocupação dos cargos de direção do clube, os entrevistados Yolanda Restani, Dawis Restani e Jair Gonzalez formaram o primeiro grupo de entrevistados. Estes levaram a pesquisa à metodologia snowball, que no Brasil é conhecida como "bola de neve". ${ }^{2}$ Ela fundamenta-se na indicação de novos sujeitos a partir dos sujeitos entrevistados, ou seja, nesse contato são indicados outros nomes no decurso das entrevistas. Desse modo, os nomes indicados pelos entrevistados foram: Paulo Cunha e Flávio Dourado, sendo eles ex-jogadores do time durante a época esportiva, e Giovanni Campos e Zilá Maria Costa, frequentadores das festividades promovidas pelo clube.

As entrevistas aconteceram no mês de fevereiro de 2014, com a participação consensual dos entrevistados. Os encontros foram previamente marcados em horário e local de acordo com a preferência dos entrevistados, e para cada participante foi apresentado e solicitado a assinatura de um Termo de Consentimento Livre e Esclarecido (TCLE) que autorizava o uso do material gravado em áudio. Todos acompanharam o processo de transcriçáo dos seus áudios para texto. Durante as entrevistas com os depoentes, a conversa se desenvolveu em uma linguagem informal, esse processo desvelou em um laço de confiança que resultou no compartilhamento de outros materiais sobre o clube. Dessa forma, Yolanda forneceu uma cópia do livro de atas

2 Uma exemplar explicação do método é posta por João Oswaldo Dewes (2013), na qual o autor sintetiza a seguinte ideia: "A amostragem em bola de neve é um método que não se utiliza de um sistema de referências, mas sim de uma rede de amizades dos membros existentes na amostra. Este tipo de método baseado na indicação de um indivíduo de um ou mais outros indivíduos é também conhecido como método de cadeia de referências. O processo começa de um certo número de sementes, pessoas selecionadas de alguma forma pelo pesquisador e que fazem parte da população- alvo. Essas pessoas, por sua vez, são incumbidas de indicar a partir de seus contatos outros indivíduos para a amostra. Segue-se assim, sucessivamente, até que se alcance o tamanho amostral desejado" (Dewes, 2013, p. 7). 
datadas de 1986 até 2004. Essas atas contêm informações sobre as finanças do clube, listagem de materiais para organizaçóes de festas, apontamentos sobre necessidade de reforma ou manutenção da sede e informes sobre o empréstimo do saláo para associados. Além disso, em anexo a esse livro, Yolanda emprestou a fotografia de uma festividade realizada na sede do clube no início da década de 1990. Após a entrevista e disponibilização desse material, Yolanda marcou outro encontro para me apresentar o estado atual da sede, na ocasião tive a oportunidade de fotografar o espaço e as antigas taças de campeonatos em que o time havia sido campeão nas décadas de 1930 e 1940.

Dado o exposto, as entrevistas, atas e fotografias compuseram o corpus documental da pesquisa, a análise integrada das fontes possibilitou compreender o clube enquanto um espaço comunitário agregador das famílias que residiam em torno da sede. Dessa maneira, explicados os pressupostos metodológicos, o presente artigo apresentará um fragmento de uma pesquisa de conclusão de curso. Isto posto, o objetivo está em analisar os relatos orais de seis moradores do bairro Porto sobre os significados de suas vivências no G. E. Rui Barbosa. Assim, a partir dessas memórias individuais e coletivas (Halbwachs, 2006), pretendo pensar o clube como um "lugar de memória" (Nora, 1993), um espaço perpassado por lembranças e esquecimentos, cuja manutençấo se deu por meio de valores, práticas, rituais e dinâmicas que, no decorrer do tempo, transformaram a identidade do clube de uma associação esportiva de futebol amador para um espaço festivo dos moradores do bairro.

Com base nisso, a delimitação temporal da pesquisa tem enfoque no período em que o clube era apenas um espaço para realização das festividades dos residentes do bairro. Dessa forma, a periodização de análise abarca o espaço temporal do ano de 1986, na qual se tem o registro da primeira reuniáo do livro de atas, até 2004, data da última reuniáo registrada no supracitado livro e período em que os entrevistados recordavam não estar mais em contato com o clube. Considerando o objetivo e delimitação temporal expostos, o presente texto náo deixará de dissertar sobre questóes referentes ao esporte. Justifico isso em razão da necessária explicaçáo sobre a origem do clube, em 1927, como uma associaçáo esportiva que pode ser compreendida por meio de uma contextualizaçáo histórica do futebol amador e da importância dessas associaçóes esportivas no cotidiano das pessoas, especialmente dos moradores de bairros operários, como foi o caso do bairro Porto. Sendo assim, ainda que o objetivo do artigo não seja um aprofundamento sobre as questôes históricas das associaçóes de futebol amador, os relatos orais da juventude esportiva dos ex-jogadores Paulo Cunha e Flávio Dourado serão incorporados no texto.

Assim sendo, o artigo está dividido em duas partes. Na primeira, com foco no esporte, apresentaremos as entrevistas de ex-jogadores de futebol do clube com o objetivo de contextualizar o surgimento do G. E. Rui Barbosa. Desse modo, pretendese dialogar com a historiografia da cidade em pesquisas referentes ao futebol de várzea, ligas, campeonatos, e a relação geográfica da localidade dos clubes amadores, tendo 
em vista que estes, assim como o G. E. Rui Barbosa, estáo situados em bairros que, no início do século XX, eram predominantemente constituídos por indústrias e moradias dos trabalhadores industriários. Na segunda parte, com foco nas festividades, apresentaremos as entrevistas com ex-associados residentes do bairro que, devido à proximidade com a sede e a rede de amizades entre os vizinhos, mantiveram o clube ativo como um espaço de lazer e sociabilidade para comemoraçóes familiares e entre amigos.

\section{A formação dos clubes sociais em Pelotas: o esporte como lazer da classe operária}

Os estudos sobre associaçóes de lazer e sociabilidades em Pelotas têm ampla produção historiográfica focada no século XIX, período de apogeu econômico da cidade. Segundo Beatriz Loner (2002), nesse período, existiam reduzidos momentos de lazer devido às convençôes sociais e códigos de conduta enrijecidos. Por exemplo, para os escravizados, as festividades religiosas eram a oportunidade para desfrutar do lazer e sociabilidade entre os membros desse grupo, do mesmo modo que para a elite, os saraus e reunióes familiares eram momentos propícios para formaçấo de novos laços familiares e construção de acordos financeiros.

Segundo Loner (2002), as associaçóes recreativas eram identificadas de acordo com etnias, classes sociais ou setores profissionais. No último caso, em grande maioria, a localizaçáo desses espaços estava próxima das moradias dos setores profissionais como, por exemplo, a Sociedade Recreativa da Luz, que é identificada por Loner (2002) como existente desde 1882, assim como as "entidades da regiáo do Porto" que, em nosso caso, corresponde ao bairro onde está localizada a sede do G. E. Rui Barbosa, na Rua João Pessoa, número 358. Embora não exista um arquivo do clube, as atas correspondentes à época em que o G. E. Rui Barbosa se caracterizava apenas como espaço recreativo, datadas de 20 de outubro de 1986 até 16 de abril de 2004, têm como página inicial a transcrição da ata número 1 , isto é, a ata de fundação, realizada em 30 de março de 1927. Se essa mostra apenas os nomes dos presentes no ato de fundaçáo do clube, os jornais de Pelotas indicam as origens de sua formaçáo como uma associação de operários da regiáo do Porto e seu nome fundacional como Grêmio Sportivo Ruy Barbosa. Segundo a notícia do jornal Libertador:

Grêmio Sportivo Ruy Barbosa - fundou-se recentemente, do qual fazem parte alguns funcionários da Alfândega e outras pessoas de valia. Primeira diretoria: pres. Joaquim Pinto da Costa e secs. José Gabriel de Souza e Pedro Ramalho; cap. geral: Oswaldo Faria. Está sob o patrocínio da Liga Dr. Augusto Simóes Lopes. (Grêmio..., 1927). 
Desse modo, se a História reconhece o futebol como um esporte de origem da elite inglesa, no Brasil, é a partir do século XX, no período histórico de formação do G. E. Rui Barbosa, que o crescimento das fábricas transforma o futebol em um "esporte proletário de massa". Bem como afirma Miguel Stédile, "propagado por marinheiros, funcionários especializados ou professores das escolas britânicas, antes limitado às elites e clubes nacionais", aos poucos foi "apropriado pelos trabalhadores, resultando na fundação de inúmeros clubes” (Stédile, 2011, p. 10).

A partir disso, podemos afirmar que a chegada do futebol em Pelotas tem relação com a presença do porto e de outros setores profissionais localizados nos bairros de residência operária. Essa afirmaçáo é análoga à cidade portuária de Rio Grande, que tem o registro do time de futebol mais antigo do Rio Grande do Sul, o Sport Clube Rio Grande, fundado por alemáes no ano de 1900. Como referenciado acima, se os trabalhadores das fábricas popularizaram esse esporte, por outro lado, isso não impediu que as relaçóes raciais formassem times étnicos europeus que, em sua grande maioria, impediam a entrada de jogadores negros. Dito isto, pensando em nível nacional e transnacional, a chegada do futebol no Brasil pode ser comparada ao início do esporte na Alemanha: tanto aqui como lá, antes da popularização, houve momentos de preconceitos, pois "a bela e heroica história do futebol em ambos os países é, claramente, um episódio da história social, da inclusão social e étnica, da consolidaçáo da cidadania" (Silva; Santos, 2006, p. 16).

Se no princípio existiam rígidas regras que impediam a participação de pessoas "nâo condizentes" com a classe e a etnia que os times ou clubes ditavam, demorou décadas para que se aceitassem negros e mestiços em times étnicos europeus como, por exemplo, entre 1906 e 1910, quando o Bangu Athletic Club, constituído por jogadores ingleses membros do corpo de funcionários da tecelagem, escalou o primeiro atleta negro da história do Brasil: Francisco Carregal. Segundo Stédile (2011), a atitude do Bangu ocorreu devido à falta de jogadores britânicos. Apesar disso, o autor pensa que a democratizaçáo social do futebol construiu laços de identidade entre a fábrica, o bairro e os operários, e o resultado dessa união "logo, resultaria na constituiçâo de uma 'elite' formada por jogadores-operários, atletas habilidosos, formalmente vinculados às empresas, mas que não trabalhavam ou eram alocados em trabalhos leves" (Stédile, 2011, p. 11).

Sobre a questão étnica, no G. E. Rui Barbosa, não possuímos informaçóes diretas sobre a composição racial do time, contudo as contribuiçóes da pesquisa de Christian Ferreira Mackedanz (2016) e duas fotografias do time indicam algumas hipóteses a serem desenvolvidas. A pesquisa desse autor abre novas interpretaçôes sobre as relaçóes étnicas no futebol pelotense: por meio de notícias dos jornais da cidade e fotografias estampadas nessas páginas, o autor disserta sobre a situação do futebol e a segregação racial na cidade entre o período de 1900 até 1930. Um exemplo da segregaçáo racial posto pelo autor está na notícia do jornal Opinião Pública, do dia 27 de outubro de 
1927, em que são anunciados jogos entre "brancos e negros". ${ }^{3}$ Nessa direção, em um comparativo entre imagens do início do século até a década de 1930, o autor revela uma gradual adesão de jogadores negros em times que antes eram majoritariamente compostos por brancos. No caso do G. E. Rui Barbosa, Mackedanz (2016) apresenta uma fotografia do ano de 1931. Abaixo, na figura 1, fotografia retirada do jornal Opiniáa Pública, podemos ver que o time parece ser composto por uma totalidade de homens brancos:

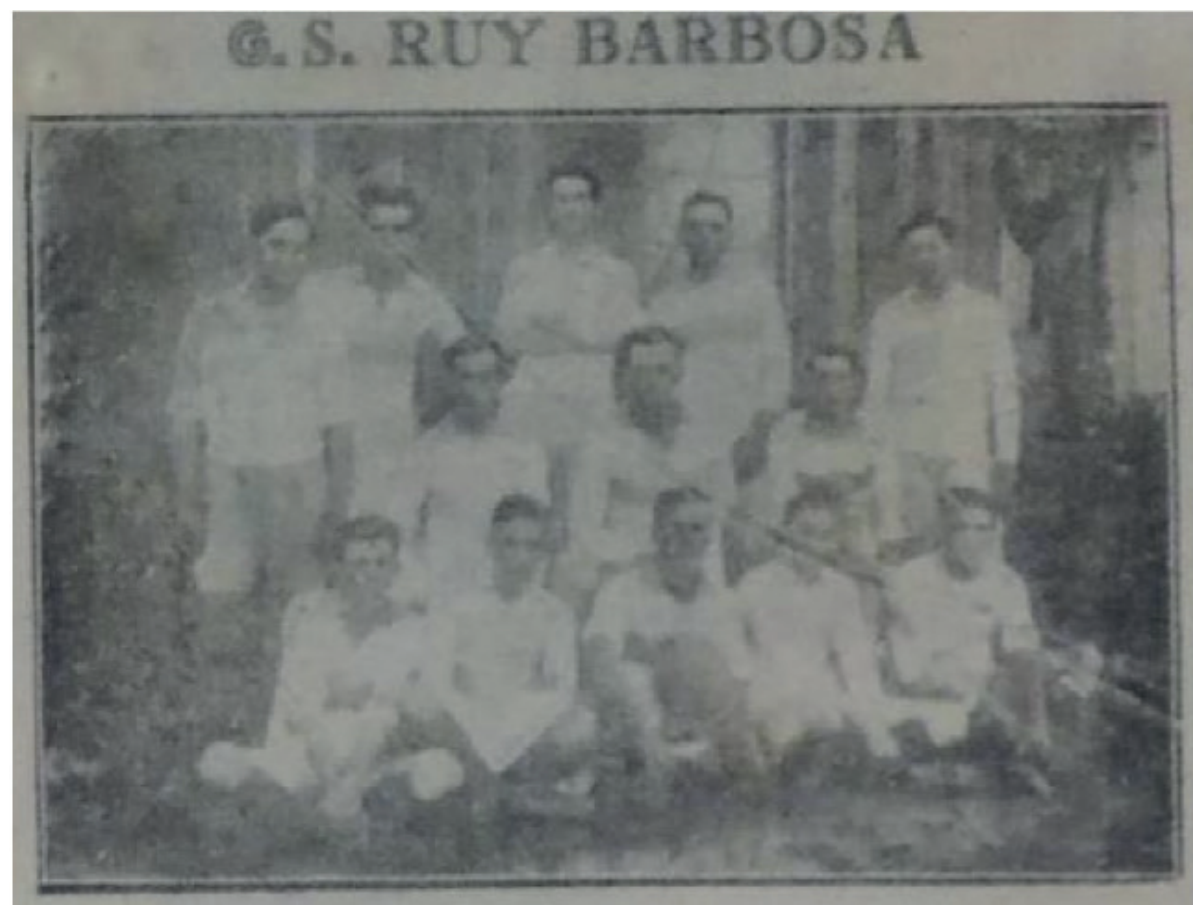

Figura 1 - Time do Grêmio Sportivo Ruy Barbosa, como era chamado na época. Fonte: acervo da Biblioteca Pública de Pelotas.

De outro modo, em 1935, temos outra fotografia em que podemos ver a diretoria, $1^{\mathrm{o}}$ quadro e $2^{\mathrm{o}}$ quadro de jogadores. Essa imagem revela um aspecto bem discutido por Mackendaz (2016) sobre os times pelotenses: "percebeu-se que nem sempre os clubes se identificavam apenas a um grupo, como elite, pequena burguesia, imigrantes, operários,

3 "Domingo próximo, provavelmente, terão os apreciadores de futebol ensejo de assistir a um encontro interessante, que promovido pelo $1^{\circ} \mathrm{C}$. A. Bancário, anualmente se repetirá. Trata-se da instituição de jogos anuais entre o selecionado de jogadores de raça branca e o selecionado de cor" (Brancos e Negros..., 1927). 
negros, etc. Em vários casos, os clubes possuíam membros que se encaixavam em dois dos grupos citados" (Mackendaz, 2016, p. 39). Como já mencionado anteriormente, se as poucas informaçóes escritas sobre o clube revelam sua origem enquanto um time formado por trabalhadores da alfândega, na imagem abaixo, podemos ver que, quatro anos após a fotografia anterior, já existiam no grupo alguns jogadores negros. Logo, talvez o G. E. Rui Barbosa fosse um time que abarcava os dois grupos citados por Mackendaz (2016): negros e operários.

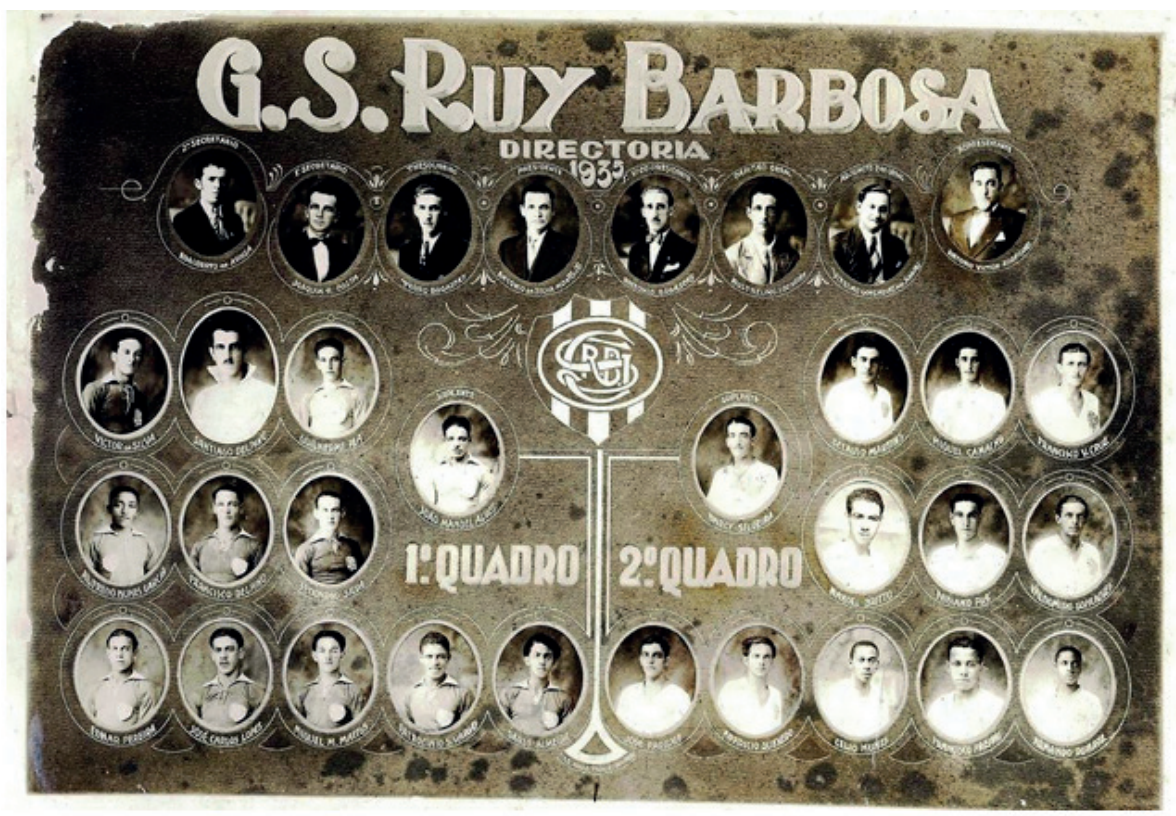

Figura 2 - Quadro Geral de 1935 do Grêmio Sportivo Ruy Barbosa, como era chamado na época.

Fonte: Mello (2019).

Falar sobre esse time também implica em contextualizar a forma como funcionava os campeonatos ou jogos amistosos à época. No que tange as ligas de futebol da cidade, Luiz Carlos Rigo (2004) aponta a existência de três: A Liga Pelotense de Futebol (1907), a Liga Cassiano do Nascimento (1914) e a Liga José do Patrocínio (1919). A Liga Pelotense de Futebol abarcava em seu princípio times de elite, o que, por conta de uma restrita adesão a outros times, resultou no surgimento das ligas Cassiano do Nascimento e José do Patrocínio. Sobre a primeira, Mackendaz (2016) afirma que existem poucas informaçôes sobre sua formação e critério para composição de times. Já a Liga José do Patrocínio era composta por times de homens negros. No que se refere ao futebol operário, segundo o mesmo autor, ligas e torneios compostos exclusivamente 
e identificados como "clubes operários" surgem somente a partir da década de 1930.

Neste sentido, sobre a participação do G. E. Rui Barbosa nessas ligas, existe pouca informação e, por isso, nosso olhar para as fontes é de caráter bastante fragmentário. Sobre a participação em campeonatos, podemos observar abaixo, nas figuras 3 e 4, a reminiscência da memória do clube através de objetos. Na figura 3, podemos ver o interior da sede e algumas taças dos campeonatos em que o clube foi vencedor (infelizmente, não foi possível anotar os anos referentes a esses jogos). Já a figura 4 confirma uma informaçáo posta por Eliseu de Mello Alves (1984) sobre o time ter sido campeão da Série B em 1941. Nesse caso, a Série B, segundo a hipótese do autor, já corresponderia ao novo nome da liga, que antes se chamava Cassiano do Nascimento. Nota-se também que nessa época o clube já era chamado pelo nome atual.
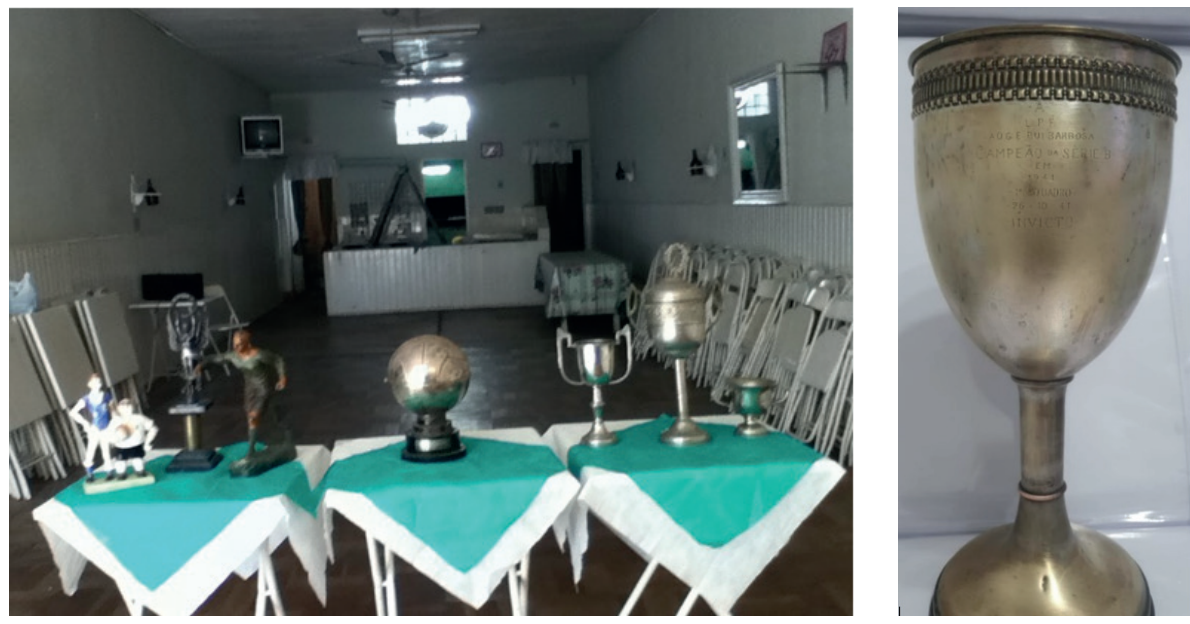

Figura 3 - Interior da Sede do G. E. Rui Barbosa.

Fonte: acervo da autora.

Figura 4 - Taça Campeão Série B de 1941.

Fonte: acervo da autora.

Se a sede abriga algumas taças dos campeonatos que o time foi vencedor, também foi possível perceber, durante a pesquisa, que outros materiais do clube (taças) estão espalhados pelo bairro, sob posse dos residentes. Essa constatação revela que, no decorrer do tempo, mesmo que a maior parte dos moradores náo tenha vivido o período mais antigo do clube, a memória esportiva do G. E Rui Barbosa se manteve viva através desses objetos. A partir dessa constatação, percebemos a existência do clube como um agenciador de pertencimento dos residentes do bairro, servindo tal como "catalisadores que concentram e reproduzem os afetos, os códigos e os conflitos que flutuam pelas ruas” (Rigo, 2007, p. 90). 
Nessa direção, as memórias de Jair Gonzalez e Flávio Dourado sobre o futebol amador no bairro Porto confirmam os clubes como espaços onde foram construídos laços de pertencimentos entre os residentes. Flávio Dourado, aposentado pela Prefeitura de Pelotas, conheceu o clube na infância, entre os anos de 1950 e 1960, quando residia na rua ao lado da sede. Flávio relata que na fase adulta se tornou jogador pelo time. $\mathrm{O}$ mesmo pode ser visto no depoimento de Jair Gonzalez, um industriário aposentado, que em meados da década de 1980 foi presidente do clube. Retomando as memórias de infância, Jair comenta que seu primeiro contato com o futebol amador aconteceu aos seis anos de idade. Este contato ocorreu através da quantidade elevada desses clubes no bairro Porto. Como pode ser visto abaixo, o relato de ambos revela aspectos do futebol no bairro:

Eu era guri pequeno e via quando eles iam disputar os campeonatos, principalmente campeonato da várzea. A gente ia pra lá pra ver os caras se fardarem, iam disputar os jogos no Fiação ou nos outros campos que existiam na várzea, que na época tinha muitos. Hoje só tem só o campo do Sudeste e mais o Osório lá embaixo, mas ó, na época, tinha muitos campos, mas o campeonato da várzea era disputado no Fiaçáo e era uma maravilha, muito bom mesmo. Quando guri pequeno, eu só vivia ali olhando, mas depois eu fui crescendo e comecei a jogar futebol com eles ali. Época muito boa, a gente era só o que existia, era futebol e cinema, então a gente gostava, era muito bom mesmo. Diga-se de passagem, que tinha um grande cidadão, Austrelino Plá de Oliveira. ${ }^{4}$ Ele foi tudo no Rui Barbosa, enquanto ele viveu, o Rui Barbosa viveu o auge da sua vida... (Flávio Dourado, 2014).

Bom, para te citar aqui vamos supor... na Gomes Carneiro mesmo existia o Cometa Futebol Clube, São João Batista de La Salle, Noventa e Nove Futebol Clube, Girafinha do Porto, Fiação e Tecidos, Penharol, Nacional, Tupinambá, Ipiranga, Tirandentes, Dragagem. Tinha tranquilamente uns vinte clubes amadores. (Jair Gonzalez, 2014).

O depoimento de Flávio Dourado e Jair Gonzalez nos remete a pensar o futebol de várzea como um lazer comum no bairro Porto. A pesquisa de Cintia Vieira Essinger (2009) revela que esse bairro, antigamente chamado de Zona da Várzea, era um lugar composto por indústrias e casas de uma arquitetura específica, algo que, através da consulta de plantas arquitetônicas do bairro, é identificado pela autora como um

4 O relato de Flávio nos leva a observar novamente a fotografia de 1935, em especial, o terceiro rosto da esquerda para a direita, na parte superior, onde estão os diretores do referido ano. Austrelino Plá, o capitão geral da diretoria de 1935 , é relembrado pela maioria dos depoentes devido a sua presença constante no clube, sendo uma das pessoas que se manteve presente desde os tempos mais antigos e que por muito tempo dedicou-se a manter as práticas esportivas e festivas ativas. Os depoentes comentam que Austrelino fez uma doação de um terreno próprio para o clube, este local é onde hoje se encontra a sede. 
ambiente de moradia e sociabilidade das famílias operárias. Um exemplo está na arquitetura das casas próximas ao clube, em que a autora identifica a especificidade de cada uma de acordo com a construtora de cada indústria. Em resumo, pode-se afirmar que existia uma estratégia de controle dos chefes dessas fábricas ao construir para seus funcionários casas próximas do local de trabalho. Desse modo, se através dos relatos de Jair e Flávio podemos afirmar que o time de futebol da Fiaçáo e Tecidos, assim como tantos outros, tinha um campo de futebol próprio, no caso do G. E. Rui Barbosa não podemos fazer o mesmo, pois temos conhecimento, apenas, da sede onde hoje o clube está localizado.

De acordo com a pesquisa de Aline Cunha (2008), os times citados por Jair e Flávio são intitulados clubes amadores da Zona da Várzea, e alguns desses mencionados por Jair são citados pela autora em sua pesquisa sobre a relaçáo entre o futebol e a identidade operária em Pelotas entre 1930 e 1960. Ao analisar esses times, a pesquisadora mostra que a maioria dos clubes operários levavam o nome das empresas para conseguir patrocínio dos chefes. Esse tipo de "ajuda" possibilitava que o time conseguisse ter fardamento, sede, campo e outros recursos, além de servir como propaganda da própria empresa, pois a vitória desses times, ao ganhar repercussão via jornais, contribuía para divulgação das empresas. $\mathrm{O}$ destaque dos times operários também influenciava na contrataçấo de empregados para a empresa, como por exemplo, o clube Fiação e Tecidos, que geralmente oportunizava empregos a bons jogadores de futebol. Outro objetivo do patrocínio estava no intuito de despertar nos trabalhadores sentimentos de pertencimento e orgulho pela empresa.

Dessa maneira, a partir do que foi posto, podemos pensar que o G. E. Rui Barbosa é diferente da maioria dos times operários, já que ele não se configura como um time com o nome da empresa patrocinadora. Embora náo exista nos jornais ou na ata fundacional alguma menção sobre escolha desse nome, acreditamos que a nomeação "Ruy Barbosa" tem relação com um contexto histórico de construção do jurista Ruy Barbosa de Oliveira como herói da Abolição e da República. Ainda sobre a vida esportiva, Aline Cunha (2008) menciona a participação do clube como padrinho do Clube Grêmio Atlético Círculo Operário. O apadrinhamento é posto pela autora como uma forma de articulação e aproximação entre os clubes. Desse modo, quando um clube de futebol era fundado, realizava-se um ritual que consistia em batizar a bandeira do clube, convidar um padrinho (pertencente a um clube mais antigo) e promover festas.

Se as festividades eram uma maneira dos clubes se manterem financeiramente ativos através das vendas de bilhetes de entradas, por meio da pesquisa de Essinger (2009) podemos verificar que esse contrato de reciprocidade ultrapassava o esporte e alcançava o relacionamento entre os residentes do bairro. A autora cita que além do esporte e das festividades realizadas nas sedes, existia o hábito das famílias se sentarem com cadeiras em frente às suas casas para conversar com os vizinhos. Essa sociabilidade 
descrita pela autora pode ser verificada como parte resultante desta pesquisa, já que obtive conhecimento sobre o passado do clube em uma ocasião como essa. Desse modo, penso que o contato social proporcionado por esses clubes reafirmava os laços de amizade entre as pessoas que residem em sua volta. As entrevistas orais com os depoentes desta pesquisa e as contribuiçóes de Essinger (2009) sobre o passado do bairro, revelam a manutenção de uma tradição de sociabilidades, e o G. E. Rui Barbosa corresponde à reminiscência de um passado em que o futebol e as relaçôes de trabalho eram pontos agregadores para formação de amizades e pertencimento no bairro.

\section{Um "lugar de memória": o findar esportivo e a construção da sede como espaço de festividades}

Nessa direçáo, as entrevistas revelaram que existiu um momento em que as práticas esportivas no G. E Rui Barbosa começaram a enfraquecer de modo que o clube se tornou apenas um local para as festividades dos associados. Sobre o processo de enfraquecimento do esporte, Jair Gonzales relata que uma das razóes foi a exigência dos jovens jogadores em receber do clube material de fardamento e deslocamento até os campos onde ocorriam as partidas. No relato abaixo, além da fala de Jair, gostaria de apresentar o relato de outro ex-jogador do clube, Paulo Cunha, um senhor, eletricista, que, assim como Flávio Dourado, residia perto do clube e se tornou jogador do time quando tinha 17 anos. Durante a conversa, Paulo relembrou os antigos jogadores do clube na década de 1950; seu relato faz referência à qualidade desses desportistas e como, naquela época, eles teriam sido valorizados se comparados ao valor dos jogadores da atualidade. Segundo Paulo, a nova geração de jovens exigia "mordomias" que tornava insustentável a continuidade das atividades esportivas no clube, devido à falta de recursos financeiros. Assim, o comentário de Jair sobre a "vaidade" dos jovens no esporte se assemelha ao de Paulo:

Então, hoje, qualquer menino que... geralmente a pessoa já nasce com vaidade. Então 'Bah, aquele guri joga bem, é bom de futebol e tal' e aí tu vais falar com ele pra joga no teu clube, aí ele diz 'tá, eu vou, mas tu vais ter que me dá tênis de marca... calça de marca, camisa de marca', por aí começa pedindo, né! E a pessoa não tem condiçôes de... ter isso aí, fica caro demais. Entáo, o futebol, antigamente, a gente carregava até o fardamento nas costas. Por exemplo, o Rui jogava aqui nos bancários... o campo dos bancários é bem retirado da localidade aqui do Rui, e nós ia a pé daqui lá nos bancários. Depois a turma começou a recuar e nós tinha que ir de caminhão, aí nós tínhamos que pagar o caminhão... o caminhoneiro para nos levar. E o futebol começou a ficar caro, pessoal já queria jantar depois do jogo, e a coisa ia assim. O futebol, o esporte futebol, é muito caro... (Jair Gonzalez, 2014). 
Nós tivemos aqui bons jogadores, tivemos Almes, que jogou até no Juventude, teve no Farroupilha [...] jogadores todos criados no Rui, mas o mais espontâneo mesmo, que mais... foi Jorge Luiz Lobo e o Aldir Tartaruga, que chamava... esse jogou no Cruzeiro de Minas. Tivemos o Paulinho Marinheiro, que teve no Vasco, mas ele escolheu... ele foi pra Marinha, mas lá, como ele era bom jogador, o Vasco queria ele, mas ele escolheu a Marinha. Naquele tempo, não dava o dinheiro que dava hoje. Se ele soubesse o que é o dinheiro de hoje, porque ele jogava muita bola. Depois de uma época, já com 30 e poucos anos, parei, aí me convidaram pra organizar como diretor de esportes. Eu andei fazendo uns jogos de 7, de saláo, fiz uns jogos amistosos, mas eu vi que o pessoal já não tava mais a fim, uma vez colocamos em um campeonato a gurizada... já queriam mordomia, queriam táxi pra ir jogar, já não era mais o mesmo ambiente que era, aí eu peguei e disse 'não, eu vou parar com o futebol'. Parei. E aí o Rui foi parando, parando e parou de jogar. E aí ficou clube social. (Paulo Cunha, 2014).

Os relatos de Paulo e Jair remetem a um processo que já estava ocorrendo na maioria dos clubes amadores do Brasil, isto é, a transição do amadorismo para a profissionalização do futebol. Na década de 1930, o governo Vargas já implementava a profissionalizaçáo do jogador de futebol, um ato que abriu precedentes para uma espetacularização do esporte, resultando mais tarde em uma sólida indústria jornalística e mercadológica em torno disso. Tendo em vista esse cenário, é possível compreender a dificuldade de Jair e Paulo na manutenção do time, visto que o futebol já representava um meio de ascensão social para muitos jovens.

Apesar disso, o clube continuou persistindo por meio do engajamento dos residentes do bairro. Nesse sentido, quando perguntei a Jair qual a importância do clube para sua vida, entre as várias expressôes emotivas, ele revelou que para além da diversão que experimentava com as excursóes de futebol, as festas organizadas na sede lhe trouxeram momentos especiais com os amigos e a família. Ao enfatizar a importância das festas, Jair revela que o espaço onde hoje se encontra o clube existia, no passado, apenas como uma pequena construção que servia para a troca de fardamento dos jogadores e armazenamento das taças conquistadas nos campeonatos. Somente a partir da década de 1980 que essa construçáo foi expandida em uma estrutura maior como um "salăo de festas":

Foi importante porque foi um clube que eu me diverti muito quando garoto. Muita excursão fui. Era a época ativa do Rui Barbosa no futebol, né! E eu muita excursão fui. Depois baile, o clube deu muito baile. Antes mesmo dessa nossa turma de oitenta e cinco, o Rui alugou o saláo aqui do lado, que era uma fábrica de móveis. Entáo fizeram muito baile naquela época, por volta dos anos sessenta e ... os anos setenta eles fizeram muito bailes, então a gente se diverte, né! Com a mocidade vem dançando... Esse, onde é o clube hoje, não, não tinha. Ele tinha uma meia-água só, o tipo de uma estrutura bem pequena, que é onde guardava as taças e o pessoal se 
fardava, só pra isso. E então nessa outra parte que o Rui alugou é que tinha mais espaço pra dança, né! E vinha até orquestra tocar porque a parte era bem ampla. Muitos bailes o Rui Barbosa deu. (Jair Gonzalez, 2014).

A extensão da sede revela a transformaçáo da identidade esportiva, que existia em uma estrutura de "meia-água", para uma identidade festiva, concretizada em um "salão de festas", direcionada para a sociabilidade dos moradores. Desse modo, identifico essa transformaçáo como a materialização do G. E Rui Barbosa enquanto um "lugar de memória", na qual os rituais (festas) representaram uma "vontade de memória" dos moradores em torno do clube. Quando Pierre Nora (1993) define os aspectos do "lugar de memória", ele o pensa de forma complexa, composto por simbologias e rituais. Nesse sentido, quando um lugar se torna um "lugar de memória" ele é "vivo", pois a dinâmica desse espaço ocorre na interaçấo das pessoas que atribuem simbologias e executam rituais. Logo, pode-se afirmar que "o que constitui ainda mais o lugar de memória, aos nossos olhos, é sua derrota em se tornar aquilo que quiseram seus fundadores" (Nora, 1993, p. 22-23). Sendo assim, em meio a um jogo de memórias individuais e coletivas que transitaram entre o passado e presente, a ressignificação da identidade do clube não excluiu o passado esportivo táo bem representado nas taças expostas nas prateleiras do saláo, elas se tornaram restos das lembranças sobre a origem do clube.

Durante a feitura das entrevistas, os fragmentos de memórias sobre o clube percorreram várias temporalidades, organizados pela trajetória individual de cada depoente. Nesse sentido, como Maurice Halbwachs (2006) afirma, as memórias individuais também se sustentam por meio de uma negociação com a memória do grupo. Posto isso, a memória coletiva das festividades, da construçáo da sede, das redes de apoio entre os vizinhos e do esporte são os fatores importantes na manutenção desse espaço e no significado que cada pessoa lhe atribuiu individualmente. Em todas entrevistas, por meio da memória individual, foi possível perceber uma memória coletiva através do mesmo sentimento - "foi uma época muito boa da nossa vida" - de tempos que relembram as amizades, a uniáo das famílias e a prática esportiva.

Retomando o relato de Jair, quando ele fala sobre as festas no período da "nossa turma de oitenta e cinco" ele se refere à diretoria de 1986, na qual sua irmá, Yolanda Restani, e seu cunhado, Dawis Restani, estiveram envolvidos no planejamento da construçáo da sede. Dawis e Yolanda são casados e aposentados, ambos se aproximaram do clube no intuito de ajudar Jair na conduçáo da diretoria, já que no referido ano Jair havia sido eleito presidente. Uma leitura progressiva do livro de atas revela que a sede é fruto de um engajamento coletivo dos residentes do bairro. A entrevista com Yolanda Restani, atual presidente do clube, expóe as demandas para a construçáo e a contribuição dos residentes do bairro através de doaçóes em material e dinheiro. Antes de ser presidente, Yolanda foi tesoureira por muitos anos e buscava administrar o fundo financeiro. Seu relato esclarece um pouco sobre a renda do clube e sua funçáo administrativa durante esse período: 
Não tínhamos muito algo a ser a... pra dedicar aos nossos associados porque a sede era pequena, não tinha muitas condiçóes, mas pelo menos era um lastro pequeno que a gente pegava no fim do mês pra pega pra água e luz... E, depois, os jantares, as festas todas seriam em prol da construção, tá... Entáo, o que que a gente... que eu mesma fazia nessa parte: juntava muitos associados todos os dias às 17:30, 18:00 da tarde, eu passava a mão nos fichários do Rui, que também trabalhei na parte da tesouraria, saía fazer a cobrança de casa em casa para que aquele dinheiro entrasse pra construção do Rui, fiz muita campanha pedindo a vizinhança toda, inclusive em geral, em prol da construçáo, desde chave de luz que podiam dar para fiação, tudo eu ia pedindo nas portas. (Yolanda Restani, 2014).

No livro de atas do clube é possível ver o empenho comunitário para construção da sede, tanto pela articulação dos diretores em terminar a obra, como pelas doaçóes dos vizinhos. Diante disso, podemos afirmar que a continuidade desse clube, desde 1927, existe devido ao sentimento de pertencimento das pessoas, sejam elas ex-jogadores ou residentes do bairro. Nesse sentido, mesmo aqueles que não vivenciaram a época mais antiga do clube, quando predominavam as práticas esportivas, apropriaram-se, de certa forma, do espaço do clube em convivência no bairro, tornando-o um meio de sociabilidade entre vizinhos. De forma geral, os depoentes citaram aspectos do clube que demonstram um sentimento de "estar em uma família". Talvez, esse sentimento tenha sido construído pela proximidade entre os frequentadores na vizinhança, o que foi reforçado pelos encontros para festejar datas comemoradas em família, como festas juninas, aniversários, Dia das Crianças, etc. Os aspectos festivos são citados, principalmente, pelas mulheres, como Yolanda:

Também tínhamos muito festas para crianças no Dia da Criança, Natal... Eu ia muito para o centro, pedia muitas doaçóes de brinquedo, fazia uma lista, claro, assinada pela diretoria e isso tudo era uma festa muito gostosa, muito boa, que olha... era muita criança! Era criança tanto para Dia da Criança, pra Natal, entendesse? E tudo com festa. Nós fazíamos os desfiles, entendesse? De festa junina, também tinha festa junina! Nós fazíamos as carreatas de caminhão para ir. Tinha as danças, essas tradicionais na festa junina, tinha tudo. Na frente do Rui, as cadeiras postas na rua e tinha dança com a cadeira e quadrilha. E sei lá, era um monte de coisa que a gente agilizava. A criançada tudo para frente e eles adoravam, e aonde eu também na mesma situação, a gente pedia doações. Às vezes participava na bebida, conseguia bebida doada por aí, às vezes o Rui, com as doaçôes dos outros, nós dávamos as bebidas... $\mathrm{E}$ a vizinhança participava com bolo, com doces, com pipoca, ou até um milho. Fazia lá dentro essas pipocas e colocava com as colegas no saquinho e, assim, a gente levava a festa, era bom demais mesmo. (Yolanda Restani, 2014). 


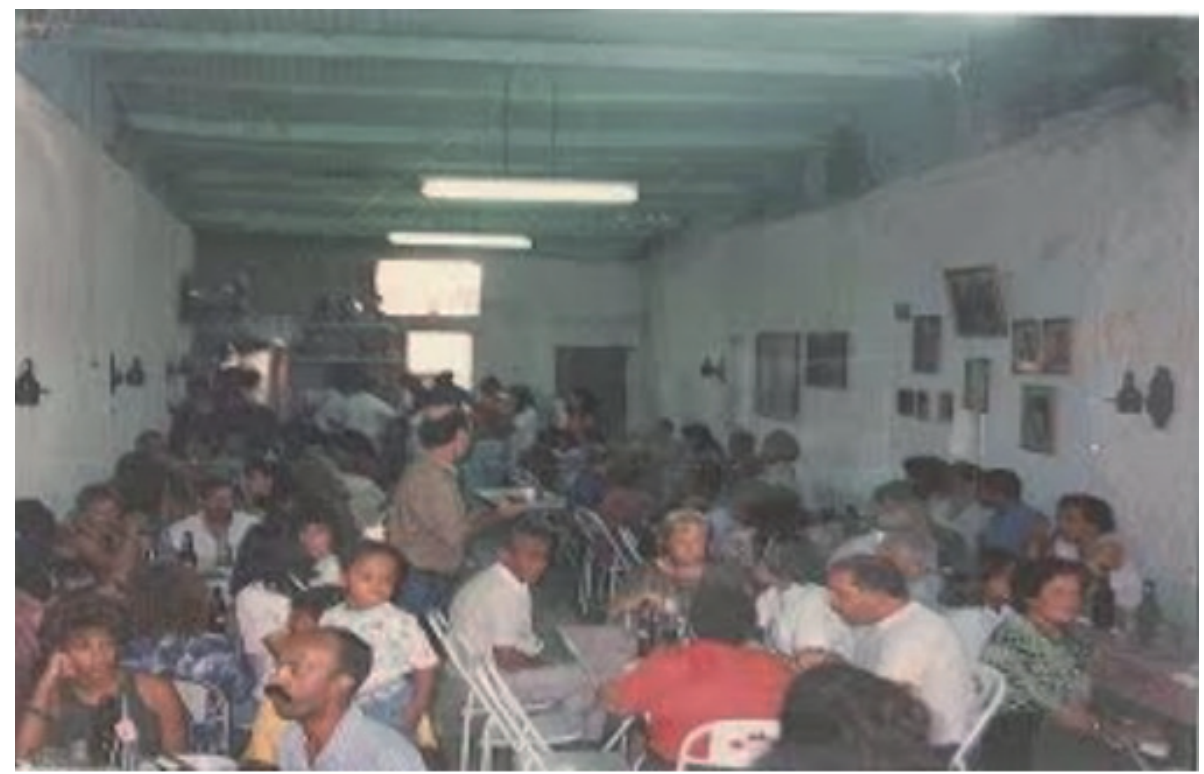

Figura 5 - Festa na sede do G. E. Rui Barbosa.

Fonte: acervo de Yolanda Restani.

O relato de Yolanda nos remete à ideia de Mayol (1996) sobre o bairro ser uma estrutura que sustenta a relaçáa entre público e privado. Nesse sentido, o bairro, sendo um espaço público, se faz a partir de um engajamento entre pessoas que se relacionam por proximidade de moradia e, em suas vidas privadas, compartilham com a vizinhança aspectos íntimos, como valores sociais e regras de conduta da família. Desse modo, o G. E. Rui Barbosa é parte dessa estrutura que dialetiza o público e o privado, é o espaço em que os residentes do bairro promoveram festas e atividades lúdicas de acordo com os valores compartilhados entre a vizinhança. Um outro exemplo de atividades está no relato de Giovanni Campos. Morador do bairro e frequentador do clube desde a infância, ele relata que uma de suas memórias marcantes eram os encontros à tarde, quando os residentes adultos jogavam cartas:

Isso foi uma das coisas tanto marcantes como outras, tantas outras, vê um jogo... Eu nunca joguei carta, náo sou jogador de carta, não gosto, mas eu adorava, amava ficar na frente de... era várias pessoas idosas jogando um tipo de jogo que eles chamavam Bisca. Não sei jogar mais, e eu vi, era maravilhoso! Um jogo que eles ficavam se dando sinal o tempo inteiro um para outro, quem tava com as cartas, e era muita sacanagem, a gente... isso me marcava muito. Entáo, hoje, eu lembro do seu Antoninho, que morreu há muito anos, era lá jogava carta. O Portella, que a gente chamava, jogava com eles ali e tantos outros... Bah! Seu, Seu Dário, Seu 
Dário também jogava com eles! Têm várias pessoas que já não estão aqui e eram coisas marcante. A gente chegava ali, só chegava para visitar o clube e a gente via que tava jogando e a gente ficava olhando e sem contar que tudo era... nada era cobrado. (Giovanni Campos, 2014).

Mesmo que o clube não tivesse mais a sua característica de lazer por meio do futebol, ele ainda mantinha a capacidade de promover outros tipos de jogos, como pode ser visto no relato de Giovanni. As interaçóes entre os moradores, através dos jogos de cartas e dos encontros das famílias em festividades, fizeram desse espaço um meio de sociabilidade que acabou por forjar os sentimentos e os valores da comunidade. Tal sentimento "familiar" alcançou laços táo fortalecidos que esse espaço serviu de âncora para ajudar os frequentadores em momentos difíceis. Nesse caso, a história da depoente Zilá Maria é um exemplo do clube como um meio de engajamento social dos residentes do bairro Porto. Zilá é uma senhora já aposentada que frequentava o clube desde a década de 1960. Durante a entrevista, ela relatou a ajuda que o clube forneceu a seu falecido irmão:

Inclusive onde eu fiz uma festa para um irmão meu que faleceu, que tocava lá no clube também, e aí a gente fez uma festa muito grande, até que ele faleceu. E nessa época a gente estava com pouco dinheiro, e aí os músicos se juntaram e fizeram essa festa, sabe... O clube encheu de gente, sabe. Foi uma coisa maravilhosa. Foi só de toda cidade de Pelotas, aqui, então, acho que não faltou nenhum, todos eles participaram. Como os amigos sabiam da situação, que ele era uma pessoa doente também, tinha asma, bronquite, sabe... E mais, ele estava sempre tocando junto, então o pessoal se juntou e fez, sabia da situaçáo dele, ele era o meu irmão, sabe... Então, a gente fez isso aí... (Zilá Maria Costa, 2014).

Nota-se, através dessa fala, a particularidade que um clube de bairro tem em comparação a clubes maiores ou elitistas. Nesse caso, todo lucro da festa foi convertido para ajudar no tratamento médico e sepultamento do irmão de Zilá. O ambiente, pequeno e frequentado por pessoas próximas, propiciou apoio aos residentes, e a música se apresentou como um elemento unificador, frequentemente comentado nas entrevistas. Nesse sentido, a história do irmáo de Zilá revela que os laços de amizade e pertencimento proporcionaram uma ajuda especial através da participação dos músicos no evento beneficente. $\mathrm{O}$ aspecto musical nesse espaço pode ser verificado, também, no relato de Giovanni, que, por meio das festividades no clube, se tornou músico. Giovanni comenta aspectos marcantes desse espaço:

O que a gente pode falar é que tinha muito músico no Rui Barbosa, era muita gente boa. E como a gente levava a família, né! O meu filho, que foi criado ali, se tornou um grande músico também. Desde menino ele era músico ali, e outros tantos que saíram dali. Hoje, tem gente que tem estúdio, de estúdio musical, né! 
Que foram criados ali no Rui Barbosa. Então, ele foi um patamar assim da parte artística e familiar. Era uma das coisas mais espetaculares, porque as famílias iam para o Rui Barbosa com o intuito de se unirem, se divertirem. Meu pai ia. Meu pai, na época, fez uma dissertação num documento, num papel, que estava em cima de uma mesa, agradecendo. Foi uma dissertaçáo muito bonita, ao ponto de que a direção do Rui Barbosa colocou em um quadro. E aquilo foi uma emoçáo para mim, ter visto meu pai participar de uma homenagem para uma simples dissertaçáo do quanto significava o Rui Barbosa. E as festas era assim: tinha as pessoas que alugavam, nem alugavam, alugava os diretores, o pessoal que convivia. Agendavam no Rui Barbosa suas festas, e muitos da volta ali faziam festas. E, geralmente, eram as mesmas pessoas, porque eram tudo amigos. Então aquilo ali era uma união das famílias na realidade, né! Mas era excelente as festas de lá! Até hoje a gente relembra isso. (Giovanni Campos, 2014).

Novamente, percebe-se a importância do clube para agregar as famílias da região, assim como a acessibilidade do espaço para aqueles que planejavam alguma festa. De modo geral, a vivência no G. E. Rui Barbosa foi interpretada pelos depoentes como um modelo a ser seguido por todos os bairros. Para eles, um espaço como esse proporciona o compartilhamento de valores, possibilidade de divertimento e construção de amizades.

\section{Conclusão}

Por meio desta pesquisa, concluo que a História Oral proporciona uma experiência pessoal singular; ouvir as narrativas das experiências desvela a transformação das sensibilidades pelo ato de fala. No ato das entrevistas, quem ouve aprende a criar a percepção sobre as expressóes sensíveis do corpo durante o processo de relembrar memórias suprimidas pelo tempo. Pelo lado profissional, a pesquisa revelou a importância de estudos sobre os clubes de futebol amadores e suas funçóes sociais nos bairros. As fontes orais revelaram um número considerável de clubes que não foram localizados nas bibliografias sobre clubes esportivos da cidade. Sendo assim, o estudo sobre o G. E. Rui Barbosa apresenta a especificidade do poder social e cultural desse espaço no cotidiano dos moradores, sendo o clube uma espécie de patrimônio do bairro. Como nas palavras dos depoentes Giovanni Campos e Zilá Maria:

É, o que se pode se falar é que esses clubes pequenos também fazem parte da nossa formação, né! Se em cada bairro fosse montado um clube, se seria que as famílias se reunissem, provavelmente fortaleceria mais as zonas como a gente chama, os bairros, né! E o Rui foi muito importante pra nós, no nosso bairro, na nossa volta aqui. Acho que era isso. (Giovanni Campos, 2014). 
É um lugar de respeito, familiar, né! E bons músicos tocam ali. E aonde a gente junta um monte de amigas sabe... E amigos e junta tudo lá. E aí eles fazem jantares, sabe... comunitário. A gente participa. É muito bom as festinhas lá e tudo, maravilhosas! Se tivesse um em cada bairro seria muito bom ... Um clube em cada bairro, que aí fazia maior intercâmbio, né! Maior troca, né! Amplia o conhecimento! As pessoas podiam se encontrar, se conhecer, conversar, né! (Zilá Maria Costa, 2014).

\section{Referências}

ALBERTI, Verena. Ouvir contar: textos em história oral. Rio de Janeiro: Editora FGV, 2004.

ALVES, Eliseu De Mello. O futebol em Pelotas. Pelotas: Livraria Mundial, 1984.

BONI, Valdete; QUARESMA, Jurema. Aprendendo a entrevistar: como fazer entrevistas em Ciências Sociais. Em Tese, Florianópolis, v. 2, n. 1, p. 68-80, jan./jul. 2005.

BRANCOS E NEGROS. Opiniāo Pública, Pelotas, p. 1, 27 out. 1927.

CUNHA, Aline Nunes da. Futebol, memória e identidade operária: uma análise sobre a prática futebolística em Pelotas nas décadas de 1930 a 1960. Dissertação (Mestrado em Educação) - UFPel, Pelotas, RS, 2008.

DEWES, João Osvaldo. Amostragem em bola de neve e respondent-driven simpling: uma descriçáo de métodos. Monografia (Bacharelado em Estatística) - UFRGS, Porto Alegre, RS, 2013.

ESSINGER, Cintia Vieira. Entre a fábrica e a rua: a Companhia Fiaçăo e Tecidos Pelotense e a criaçăo de um espaço operário Bairro Várzea, Pelotas, RS (1953- 1974). Dissertação (Mestrado em Memória Social e Patrimônio Cultural) - UFPel, Pelotas, RS, 2009.

GRÊMIO Sportivo Ruy Barbosa. O Libertador, Pelotas, p. 5, 31 mar. 1927.

HALBWACHS, Maurice. A memória coletiva. Tradução de Beatriz Sidou. São Paulo: Centauro, 2006.

LONER, Beatriz Ana. Pelotas se diverte: clubes recreativos e culturais do século XIX. História em Revista, Pelotas, v. 8, 2002.

MAYOL, Pierre. Morar. In. CERTEAU, Michel de; GIARD, Luce; MAYOL, Pierre. A invençāo do cotidiano: 2. Morar, cozinhar. Tradução Ephraim Ferreira Alves e Lucia Endlich Orth. Petrópolis: Vozes, 1996. p. 17-29.

MACKEDANZ, Christian Ferreira. Racismo "nas quatro linhas": os negros e as ligas de futebol em Pelotas (1901-1930). Dissertação (Mestrado em História) - UFPel, Pelotas, RS, 2016.

MEIHY, João Carlos Sebe Bom. Manual de história oral. São Paulo: Ediçóes Loyola, 2005.

MELLO, Sérgio. Distintivo Raro, de 1935: Grêmio Sportivo Ruy Barbosa - Pelotas (RS). História do Futebol, 1 abr. 2019. Disponível em: https://historiadofutebol.com/blog/?p=120673. Acesso em: 27 jan. 2021.

NORA, Pierre. Entre memória e história: a problemática dos lugares. Projeto História, São Paulo, n. 
10, jul./dez.1993.

RIGO, Luiz Carlos. Amizade, pertencimento e relaçóes de poder no futebol de bairro. Pensar a Prática, v. 10, n. 1, p. 83-98, 2007.

RIGO, Luiz Carlos. Memórias de um futebol de fronteira. Pelotas: Editora Universitária UFPel, 2004.

SILVA, Francisco Carlos Teixeira da; SANTOS, Ricardo Pinto dos. Memória social dos esportes: futebol e política: a construção de uma identidade nacional. Rio de Janeiro: Mauad, 2006.

STÉDILE, Miguel Enrique. Da fábrica a várzea: clubes de futebol operário de Porto Alegre. Dissertação (Mestrado em História) - UFRGS, Porto Alegre, RS, 2011.

\section{Fontes orais}

CAMPOS, Giovanni [55 anos]. [fev. 2014]. Entrevistadora: Letícia Portella Milan.

Pelotas, RS, 15 fev. 2014.

COSTA, Zilá Maria Costa [65 anos]. [fev. 2014]. Entrevistadora: Letícia Portella Milan.

Pelotas, RS, 22 fev. 2014.

CUNHA, Paulo [73 anos]. [fev. 2014]. Entrevistadora: Letícia Portella Milan.

Pelotas, RS, 20 fev. 2014.

DOURADO, Flávio [70 anos]. [fev. 2014]. Entrevistadora: Letícia Portella Milan.

Pelotas, RS, 5 fev. 2014.

GONZALEZ, Jair [72 anos]. [fev. 2014]. Entrevistadora: Letícia Portella Milan.

Pelotas, RS, 10 fev. 2014.

RESTANI, Yolanda [78 anos]. [fev. 2014]. Entrevistadora: Letícia Portella Milan.

Pelotas, RS, 9 fev. 2014.

Recebido em 27/01/2021.

Aprovado em 12/07/2021.

Fonte de financiamento: Coordenação de Aperfeiçoamento de Pessoal de Nível Superior (Capes) - Bolsa.

Conflitos de interesse: nada a declarar. 